\title{
Explaining diversity of livestock-farming management strategies of multiple-job holders: importance of level of production objectives and role of farming in the household
}

\author{
C. Fiorelli ${ }^{\dagger}$, B. Dedieu and J.-Y. Pailleux \\ INRA - UMR1273 Métafort, équipe Transformation des Systèmes d'Elevage, F-63122 Saint-Genès Champanelle, France
}

(Received 19 October 2006; Accepted 5 June 2007)

\begin{abstract}
We characterised the livestock-farming management strategies of multiple-job holders and identified which variables contributed most to the differentiation of these strategies. We hypothesised that they would mainly be differentiated by the contribution of the farming income to the total household income and the availability of the household members for farming. The multiple-job holding livestock-farmer's motivations, decisions and actions about both multiple-job holding and livestock farming were obtained in semi-directed interviews of 35 sheep farmers who held multiple jobs, on farm and off farm. They were synthesised into six variables characterising the diversity of the livestock-farming objectives and management guidelines. Thanks to a multiple factorial analysis, we showed that the diversity of the sheep-farming management strategies of multiplejob holders was better explained by two factors 'level of motivation of the farmer to get high technical results' and 'more personal fulfilling v. the family business conception of farming', than the factors we hypothesised. Within our sample, the performances ranged from 0.7 to 1.4 weaned lambs per ewe per year. Six sheep-farming management strategies were identified. They illustrated the importance of the level of production objectives and of farming income expectation, which were found to be independent, in explaining diversity. No direct relationship between farm work organisation and sheep-farming management strategy was identified. Explaining the diversity of the livestock-farming management strategies of multiple-job holders appears to require that all the benefits expected from farming and their hierarchy be identified before analysing how they are translated into production objectives and management guidelines.
\end{abstract}

Keywords: farming systems, livestock-farming management, part-time farming, sheep farming, work organisation

\section{Introduction}

Besides farming, multiple-job-holding farmers perform at least another revenue-generating activity, often off farm. Farming systems of multiple-job holders have to be supported because they contribute to the sustainable development of rural areas. At the household scale, through diversifying the income sources, multiple-job holding can improve the income of households and permit adjustments 'to changes in agriculture, family needs and shifts in the external environment' (Fuller, 1991). It also enables the farm household to withstand falling agricultural prices and falling agricultural public subsidies. At the rural territory scale, through enabling some households to live in the rural area and keeping farming even on small farms, multiple-job holding helps to maintain the rural population levels. In the

${ }^{\dagger}$ Email: fiorelli@clermont.inra.fr year 2000, multiple-job-holding farmers represented one farmer out of four in the European Union.

Supporting the livestock-farming systems of multiple-job holders to improve their survival, their contribution to the agro-food-supply chain and to the land maintenance requires knowledge about the diversity of these systems from both technical and social points of view.

How can the diversity of livestock-farming systems be explained, taking into account both the technical aspects of the livestock-farming operation and the diverse role of livestock farming in the household? To explain the diversity of multiple-job holding, social science studies have underlined the importance of two factors: contribution of farming income to total household income and implication of the household members in the off- and on-farm activities (Barlett, 1986; Blanchemanche, 2000). These two factors are relevant to analyse livestock-farming management strategies, because a livestock-farming management 
strategy consists of a set of livestock-farming objectives and management guidelines (Gibon et al., 1996), which gives sense to the observed livestock-farming operation. The contribution of the farming income to the total household income can be considered as an indicator of the farming objectives (Veysset et al., 2005), while the implication of the household members in the off- and on-farm activities can be considered as an indicator of the familial labourforce availability for farming, which can be a limiting factor constraining the livestock management (Madelrieux et al., 2004). So we hypothesised that these two factors would mainly differentiate the livestock-farming management strategies of multiple-job-holding farmers. This study aimed at characterising the diversity of the livestock-farming management strategies of multiple-job holders by analysing their motivations, decisions and actions about both multiple-job holding and livestock farming and identifying which variables contribute most to differentiation of these strategies.

\section{Material and methods}

\section{Sampling and surveying the farms}

The study was carried out in 2004 in the herbaceous mountains of Auvergne, a region in the Central France. In this region, in 2000, the farm manager or his/her spouse combined gainful activities both on and off farm in $23 \%$ of the farms that had ruminants (more than five cows or 20 ewes) and the related year-sale figure was more than 5350 euros (Fiorelli et al., 2005). We focussed on sheep farms because the sheep sector appeared to be very concerned about a better knowledge of multiple-job holders to adapt their extension policy (Fiorelli and Dedieu, 2004). These farms raised $26 \%$ of the total ewes (Fiorelli et al., 2005). The stratification of the population was based on three criteria, which we assumed could reveal differences in livestock-farming management strategies: (1) flock size (linked to the income expectation); (2) off-farm activity independent worker $v$. salary man (linked to the working rhythms); (3) commercialisation scheme through lamb producers groups $v$. independent sellers (linked to the production goals). We gained access to the data, thanks to the technical staff of the lamb producers' groups or to the shearing enterprises' staff.

Thirty-five multiple-job-holding sheep farmers were interviewed in a mountainous area between 500 and $1000 \mathrm{~m}$ above sea level, where permanent pasture dominates and is rather extensively used. Flock size ranged from 46 to 620 ewes, associated with either fixed or unfixed working hours in off-farm activities: two-thirds of the farm managers were salaried people, so they had been considered having fixed working hours, the remaining one-third were independent workers or farmer's union-elected person with more unfixed working hours. Salaried people worked as workman, postman, inseminator, carpenter, butcher, bus driver, farm adviser and replacement service worker.
Independent workers were bakers, woodmen, banking contractors, electricians, shopkeepers and farming contractors. Households were made of 29 couples and six singles. People had been farming on average for 17 years (Table 1). Farming area was 45 ha on average (Table 1). Of the farming area, $91 \%$ was used as the main fodder area. Sheep farming was the main production in most of the surveyed farms even though 16 of them grew crops as well and 12 had equine animals. The average stocking rate was 0.9 livestock unit per ha. Most of the farm crossed hardy breed ewes (Rava, Blanche du Massif Central) with meat rams (Charollais, Ile de France). Only four farms reared pure meat breed (Texel, Charollais). Two-thirds of the sample were made of farmers who sold their lambs through a lamb producers' group and one-third to independent buyers.

\section{Interviews content}

Interviews were semi-directed and lasted between 2 and $3 \mathrm{~h}$. They explored (1) the history: evolution of the combination of off- and on-farm activities and farming-activity dynamics; (2) the present situation is related to who lives and works on farm and off farm in the household, and what the money expectations from livestock activity are; (3) flock management practices; (4) farm work organisation; and (5) flock productivity and type of lamb-selling profile.

\section{Analysis methods}

The analysis consisted of three steps: building synthetic variables, identifying major factors of differentiation of the strategies and identifying sheep-farming strategy archetypes.

The first step aimed at simplifying the data into six synthetic variables that integrated linkages and consistencies between elementary facts or practices.

Data were made of quantitative information (structures and flock performances) and also of qualitative ones based on what farmers said about history, farm-income expectations, the work organisation and flock management practices. A synthetic variable is a data group related to some facts on history or practices, which appear consistent and make sense in characterising and distinguishing livestockfarming management strategies (Girard and Hubert, 1999). To build synthetic variables, we used the 'repertory grid' method developed by Girard et al. (2001). This method

Table 1 Characteristics of the 35 part-time farms surveyed

\begin{tabular}{lcccc}
\hline \hline & Minimum & Maximum & Mean & s.d. \\
\hline No. of ewes & 46 & 620 & 219 & 169 \\
Farming area (ha) & 13 & 120 & 45 & 30 \\
$\%$ of the farming area which & 44 & 100 & 91 & 15 \\
is used as the main fodder area & & & & \\
Stocking rate (livestock unit per ha) & 0.54 & 1.32 & 0.87 & 0.26 \\
Duration of farming (year) & 1 & 38 & 17 & 10 \\
\hline \hline
\end{tabular}


Farming management strategies of multiple-job holders

taken from 'knowledge engineering' consists in building a 'series of dichotomic attributes', here called 'variables', defined by extreme situations encountered in the studied cases, and then identifying intermediate situations, here called 'modalities'. We formalised four or five modalities per variable, each modality having roughly the same frequency. Each farmer was connected to only one modality per variable.

The variable we built concerning the flock level was inspired by the concept of the lamb-production strategy defined by Hubert et al. (1993) as "how many lambs are wished by the farmer to be produced, what kind of, when and how'. The variables we built concerning the household level were inspired (1) by the studies of Fuguitt (1961) and Blanchemanche (2002) in representing the farm-income expectations, farming dynamics, pattern of the activities of members of the household and its chronology and (2) by studies of Dedieu and Servière (2001) and Madelrieux et al. (2004) in representing how the households organise farm work.

The second step aimed at identifying factors differentiating the sheep-farming management strategies. We made a multiple factorial analysis (MFA), using the version 5.5 of SPAD (Système Portatif d'Aide à la Décision) software, and combining the 35 observation units, six variables and their 25 modalities. All variables and observation units were equally loaded.

The third step aimed at identifying sheep-farming management strategy archetypes. For this purpose we used graphic representations that amplify visual cognition, as described by Bertin (1977) and Card et al. (1999). To design a graphic representation, we first generated a matrix table gathering the 35 observed units in lines, the six variables in columns and the 25 modalities in the cells. Then we attributed the same set of five colours to the five modalities per column. Subsequently, to identify associations between modalities of the variables, we iteratively reorganised the lines, columns and colours of the table with the goal of obtaining the largest areas in one colour. These areas represent groups of units that have identical associations of modalities. Four strategy archetypes were defined on the basis of matching colours in at least the three columns corresponding to (1) lamb-production strategy variables, (2) farm-income expectation and (3) work organisation strategy. Two additional archetypes were defined on the basis of three matching colours in all six columns. Final groups consisted of archetypes and farmers who had similar associations of modalities.

\section{Calculation of the numerical productivity}

Productivity was calculated from number of ewes present on the farm on the day of the survey, number of lambs sold and replacement ewe lambs declared by the farmer. For the 2/3 farms selling their lambs to producers groups, the ratio was validated by the data from these groups.

\section{Results}

Six variables and their modalities to characterise the diversity in sheep-farming management strategies Synthetic expression of the six variables and their modalities, and the number of units per modality are detailed in Table 2. They are distinguished as follows.

The lamb-production strategy (Pro). Four lamb-production strategies were identified, differing in reproduction and selling practices (Table 3). They differed in terms of how much the farmer stepped in to manage the flock and to plan lamb production.

Farm-income expectations (Inc). Four levels of farm-income expectations to cover the household needs were observed, and they ranged from 'non-existent' to 'very important'.

Dynamics of the dimension of the farm and of the place of lamb production among other agricultural productions (Dyn). Four patterns of evolutions of farm dimension and place of the lamb production among other agricultural activities differed by their aspect linear $v$. chaotic.

Chronology of the combination of off/on-farm activities (Chro). Chronologies of the combination of off- and onfarm activities were diverse: off-farm activity was not always the second one to appear after farming in the household. The chronology often revealed the rationale of the combination of activities with respect to how much the extent of the combination of activities are chosen or undergone and how much priority is given to farming with regards to the evolution of time and money investments.

Who in the household works on and off farm (Hou). Four patterns of combination of activities were identified according to the involvement of the spouses in on and off farm lucrative activities. They differed among households according to their composition (i.e. number of spouses involved on farm and number having off-farm jobs) and according to the conception of farming by the members of the household (familial $v$. personal).

The farm work organisation strategy (Wor). To meet the work to be done on the farm in addition to one or two other activities, five strategies were identified, differing in the levers they mobilise (labour force, availability left by the off-farm activity, livestock management by simplifying or postponing some tasks) and in their time-scale (from day-to-day $v$. on a yearly basis). 
Fiorelli, Dedieu and Pailleux

Table 2 Empirically constructed variables, modalities and number of household per modality

\begin{tabular}{|c|c|}
\hline Variables & Modalities (number of household) \\
\hline Lamb production strategy & $\begin{array}{l}\text { Pro1 }=\text { Unplanned reproduction and selling with diversified sold products }(11) \\
\text { Pro } 2=\text { Free reproduction, } 100 \% \text { finished lambs sold }(7) \\
\text { Pro3 }=\text { Meat/pure bred rams, several mating periods per year, } 100 \% \text { finished lambs sold, one quality contract (4) } \\
\text { Pro } 4=\text { Meat/pure bred rams, three lambings per } 2 \text { years, several quality and out-of-season lambs selling contract (13) }\end{array}$ \\
\hline Farm income expectations & $\begin{array}{l}\text { Inc1 }=\text { Money not a question }(4) \\
\text { Inc2 }=\text { Controlled hobby }(7) \\
\text { Inc3 }=\text { Complement }(9) \\
\text { Inc } 4=\text { Important }(15)\end{array}$ \\
\hline Farming dynamic & $\begin{array}{l}\text { Dyn } 1=\text { Increasing of farming, especially of the sheep production (11) } \\
\text { Dyn2 }=\text { Stable sheep farming (11) } \\
\text { Dyn3 }=\text { Increases and decreases, only sheep farming (9) } \\
\text { Dyn4 }=\text { Phases with and without sheep or with more and more farm productions (4) }\end{array}$ \\
\hline $\begin{array}{l}\text { Chronology of the } \\
\text { combination of off- } \\
\text { and on-farm activities }\end{array}$ & $\begin{array}{l}\text { Chro1 }=\text { Farming }=1 \text { st activity }(4) \\
\text { Chro2 }=\text { Farming }=2 \text { nd activity (13) } \\
\text { Chro3 }=\text { Always part-time farmer (14) } \\
\text { Chro4 }=\text { Chaotic: successive interruptions and come back of on- or off-farm activities (4) }\end{array}$ \\
\hline Household composition & $\begin{array}{l}\text { Hou } 1=\text { One farmer alone works both on and off farm (7) } \\
\text { Hou } 2=\text { Couple but only one spouse works on-farm and this spouse works off farm as well (8) } \\
\text { Hou } 3=\text { Couple with both spouses working on-farm and only one spouse off farm (9) } \\
\text { Hou } 4=\text { Couple with both spouses working on- and off farm (11) }\end{array}$ \\
\hline $\begin{array}{l}\text { Ways to face the work } \\
\text { to be done on the farm }\end{array}$ & $\begin{array}{l}\text { Wor1 = Livestock management mainly adapted to the off-farm activity rhythm on a day-to-day basis (4) } \\
\text { Wor } 2 \text { = Adaptation of the free-time left by the off-farm activity to the farming needs on both a year or a daily basis (8) } \\
\text { Wor3 = Adaptation of the labour force on-farm to the farming needs (4) } \\
\text { Wor4 = Adaptation of both the livestock management and the labour force on-farm (5) } \\
\text { Wor5 = Adaptation of both the livestock management and the free-time left by the off-farm activity (14) }\end{array}$ \\
\hline
\end{tabular}

Table 3 Construction of the variable 'lamb production strategy': four modalities

\begin{tabular}{|c|c|c|c|c|c|}
\hline & & Pro1 & Pro2 & Pro3 & Pro4 \\
\hline \multirow[t]{3}{*}{$\begin{array}{l}\text { Reproduction } \\
\text { practices }\end{array}$} & Mating period & $\begin{array}{l}\text { Rams and ewes } \\
\text { together all year } \\
\text { round }\end{array}$ & $\begin{array}{l}\text { Rams and ewes } \\
\text { together all year round }\end{array}$ & $\begin{array}{l}\text { Several mating periods } \\
\text { in the year }\end{array}$ & $\begin{array}{l}\text { Three lambing periods per } \\
2 \text { years with tree mating } \\
\text { periods in the year }\end{array}$ \\
\hline & $\begin{array}{l}\text { Choice of specific } \\
\text { rams }\end{array}$ & No & No & $\begin{array}{l}\text { Differentiation of ram } \\
\text { for meat production and } \\
\text { (pure breed ram) for } \\
\text { replacement }\end{array}$ & $\begin{array}{l}\text { Differentiation of the ram } \\
\text { breeds for meat and } \\
\text { replacement }\end{array}$ \\
\hline & Planning & No & Roughly & Yes & Yes \\
\hline \multirow[t]{3}{*}{$\begin{array}{l}\text { Selling } \\
\text { practices }\end{array}$} & $\begin{array}{l}\text { Types of sold } \\
\text { products }\end{array}$ & $\begin{array}{l}\text { Diversity of lambs in } \\
\text { heterogeneous } \\
\text { groups }\end{array}$ & Only finished lamb & Only finished lamb & $\begin{array}{l}\text { Diversity of lambs in } \\
\text { homogeneous groups } \\
\text { (stored, finished, breeding) }\end{array}$ \\
\hline & $\begin{array}{l}\text { Commitment to } \\
\text { the producer } \\
\text { groups }\end{array}$ & No & No & $\begin{array}{l}\text { Contract for only one } \\
\text { quality sign }\end{array}$ & $\begin{array}{l}\text { All the quality signs } \\
\text { sometimes including a } \\
\text { contract on a number of } \\
\text { lamb sold out-of-season }\end{array}$ \\
\hline & Planning & No & Roughly & Yes & Yes \\
\hline
\end{tabular}


Analysis of diversity of sheep-farming management strategies and their performances

The eigenvalues and the loadings of each factor of the MFA are presented in Table 4. The biggest step was first between the sixth and the seventh factors, and second one between the second and the third factors. We used the first two factors (loadings 14 and 13\% respectively) to explain the diversity of livestock-management strategies. Table 5 details contributions and coordinates of the most significant modalities.

The first factor is related to the motivation of the farmer to get high technical animal performances according to the 'main stream technical message' of the producers' groups which is stated in terms of animal productivity and valorisation in the quality supply chains. It opposes situations where

(a) Farming was done by choice with a strong technical motivation for obtaining high technical results. It was

Table 4 Loadings and eigenvalues of the first 10 factors (out of 19)

\begin{tabular}{rcc}
\hline \hline Factor & Eigenvalue & Loading (\%) \\
\hline 1 & 0.4336 & 13.69 \\
2 & 0.4159 & 13.13 \\
3 & 0.3660 & 11.56 \\
4 & 0.3296 & 10.41 \\
5 & 0.2873 & 9.07 \\
6 & 0.2371 & 7.49 \\
7 & 0.1812 & 5.72 \\
8 & 0.1677 & 5.30 \\
9 & 0.1428 & 4.51 \\
10 & 0.1176 & 3.71 \\
\hline \hline
\end{tabular}

realised with three lambings every 2 years and the sale of lambs with quality signs replacement, finishing and storing, and out-of-season contracts with the producers' groups (Pro4). Sheep farming started by choice after working off farm (Chro2), thanks to a small farm heritage.

(b) The farmer had to work off-farm for economical reasons and had no technical farming target. The farmer had no target in terms of a number of sold lambs or a type of lamb or a period of selling (Pro1). Economical farming results imposed combining activities (Chro3). Farm work was organised in time available aside from the off-farm activities (Wor1).

The second factor is related to the 'conception' of farming of the farmer. It opposes situations where

(a) Farming was considered as a kind of leisure of only one member in the household. Farm-income expectations were limited to no loss (Inc2). Only one person of the couple worked on farm and he/she combined off-farm activities (Hou2). Farm size (Dyn3) and flock management were adjusted to the free time left by off-farm activities, within a year and across the years (Wor4).

(b) Farming was considered as a familial and professional activity. Money expectations were important (Inc4). Both members of the couple were involved on the farm (Hou3). Changes or diversification of the farm productions were made (Dyn4). The extension of the labour force compensated for the limited time availability of the couple to do the farm work, due to the off-farm activities (Wor3).

Six groups of livestock-management strategies were identified (Figure 1). They were characterised by specific

Table 5 Contribution to the factors 1 and 2 and coordinates of the most significant active modalities

\begin{tabular}{|c|c|c|}
\hline Name of the active modalities & Contribution (\%) & Coordinates \\
\hline \multicolumn{3}{|l|}{ Factor $1=$ level of motivation of the farmer to get good animal production performances ( $14 \%$ of the diversity) } \\
\hline Wor1 = Livestock management mainly adapted to the off-farm activity rhythm on a day-to-day basis & 19.8 & -2.12 \\
\hline Pro1 = Unplanned reproduction and selling with diversified sold products & 15 & -1.11 \\
\hline Dyn $4=$ Phases with and without sheep or with more and more farm productions & 12.6 & -1.13 \\
\hline Chro2 $=$ Farming $=2$ nd activity & 8.5 & 0.75 \\
\hline Pro4 $=$ Meat/pure bred rams, 3 lambing per 2 years, several quality and out-of-season lambs selling contract & 8.2 & 0.76 \\
\hline Inc1 = Money not a question & 7.2 & -1.28 \\
\hline Chro3 $=$ Always part-time farmer & 6.9 & -1.25 \\
\hline Dyn1 = Increasing of farming, especially of the sheep production & 6.6 & 0.74 \\
\hline \multicolumn{3}{|l|}{ Factor $2=$ the more or less personal fulfilling versus the familial business conception of farming $(13 \%$ of the diversity) } \\
\hline Inc2 = Controlled hobby & 20.2 & -1.59 \\
\hline Dyn3 $=$ Increases and decreases, only sheep farming & 16.7 & -1.91 \\
\hline Hou $2=$ Couple but only one spouse works on-farm and this spouse works off-farm as well & 11 & -1.09 \\
\hline Wor4 $=$ Adaptation of both the livestock management and the labour force on-farm & 9.6 & -1.29 \\
\hline Wor $3=$ Adaptation of the labour force on-farm to the farming needs & 7.5 & 1.28 \\
\hline Hou3 $=$ Couple with both spouses working on-farm and only one spouse off-farm & 7.4 & 0.85 \\
\hline Chro3 = Always part-time farmer & 6.2 & -1.16 \\
\hline Dyn4 $=$ Phases with and without sheep or with more and more farm productions & 5.5 & 0.73 \\
\hline Inc4 = Important & 3.3 & 0.44 \\
\hline
\end{tabular}


combinations of modalities of the six variables active in the MFA. Data on structural characteristics and productive performances (inactive variables) are summarised in Table 6.

The 'shock absorber strategy'. The three driving forces of this management strategy were the following: (1) absence of productivity or economical goals because these households made their living from off-farm activities; (2) strong will to keep the flock whatever the farm economical results and time they had to farm and (3) choice of doing only what was important to them in breeding and to postpone or to give up other things to be done. The strategy consisted in giving the priority to the off-farm activities in contributing to the household income and also in the work organisation. The off-farm activities had often been started after economic difficulties had been encountered on the farm. Most of the time, both members of the couple or the farmer himself combined several off-farm activities. The flock management consisted in adjusting the flock operation from day to day, according to their availability on farm. More concretely, the farmers chose to postpone some tasks on the flock or on the land. They also chose to manage all animals the same way whatever their conditions and preferred to maximise the grazing period duration. Selling

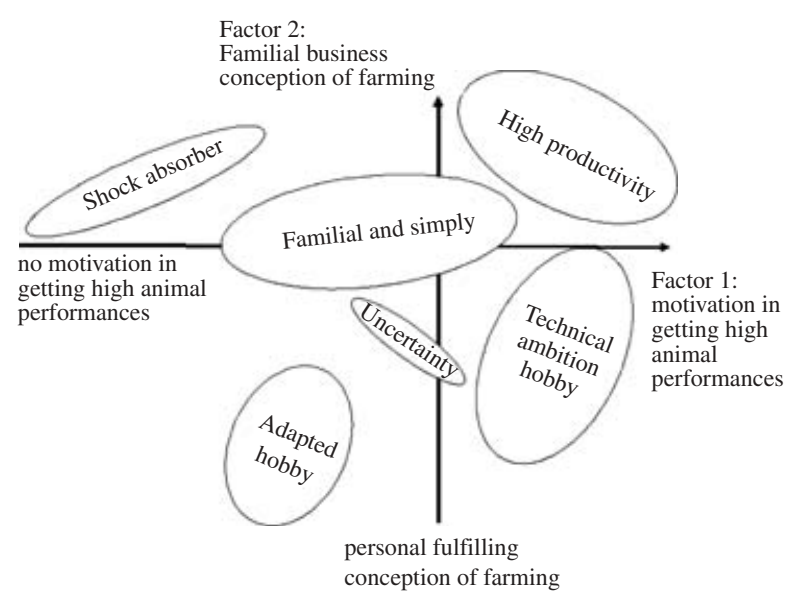

Figure 1 Six sheep farming management strategies differentiated by two factors (multiple factorial analysis, MFA). and replacement were decided according to market opportunities and determined by the cash need of the family, thus not much according to flock management demographic rules. Animal performances were modest, less than one weaned lamb pro ewe and pro year.

The 'high production strategy'. This strategy aimed high flock productivity and economic profitability. It consisted in implementing a highly productive reproduction and feeding management such as three lambing every 2 years, and also differentiated feed diets according to the particular animal's requirements. Farmers were very much involved in and sometimes even committed to the producers' groups, contributing to the quality or out-of-season or pure-bred lamb deliveries. This strategy relied on either having time for farming because of time available during the day aside from the off-farm activities (e.g. they worked off-farm only at night, or only on week-ends) or they compensate for the absence of themselves on farm through increasing the salaried or familial labour force on farm. They did not want to jeopardise the production goals. That was particularly but not only - the case of the farmers with a mandate in the farming unions. Animal performances globally reached a high level (1.4 lambs per year per ewe) but were very variable from one farm to another.

The 'adapted hobby strategy'. This livestock-management strategy aimed at doing 'well' both off- and on-farm activities aside family. It consisted in adapting both flock management and having time after attending to the offfarm activity. The farmers considered farming as a hobby they enjoyed very much and worked alone on farm, with a technical motivation. They did not want to make money or lose money with sheep farming. Most of the time, they adapted both the rhythm of the off-farm activity and farming, especially the livestock-management calendar and the size structure. Indeed, they had some expectation in terms of the type and the number of lambs they wanted to produce or the period in which they wanted to sell their lambs, but at the same time they did not want to have their off-farm activity constrained by farming. So, for example, they chose to have only one lamb mating period that would suit the possibility of taking many days off of their off-farm

Table 6 Farming characteristics pro-farm management strategy (min-max/mean)

\begin{tabular}{lccccc}
\hline \hline Farm management strategy & No. of farm & $\begin{array}{c}\text { Farm size } \\
\text { (ha) }\end{array}$ & No. of ewes & $\begin{array}{c}\text { Duration of } \\
\text { farming (year) }\end{array}$ & $\begin{array}{c}\text { Productivity (weaned } \\
\text { lamb per ewe per year) }\end{array}$ \\
\hline Shock absorber strategy & 4 & $40-60 / 46$ & $75-225 / 160$ & $12-38 / 26$ & $0.8-0.9 / 0.9$ \\
High productivity strategy & 8 & $13-120 / 70$ & $105-620 / 399$ & $1-36 / 21$ & $0.9-1.6 / 1.4$ \\
Technical ambition hobby strategy & 7 & $13-28 / 18$ & $70-400 / 175$ & $1-30 / 9$ & $1-1.4 / 1.2$ \\
Adapted hobby strategy & 3 & $20-45 / 30$ & $80-110 / 92$ & $15-17 / 16$ & $1.1-1.5 / 1.3$ \\
Familial and simply strategy & 11 & $16-100 / 45$ & $50-600 / 199$ & $6-21 / 15$ & $0.7-1.2 / 1.1$ \\
Uncertainty strategy & 2 & $16-18 / 17$ & $46-90 / 68$ & $6-17 / 12$ & NC/NC \\
\hline \hline
\end{tabular}

Abbreviation: $\mathrm{NC}=$ not calculated. 
commitments. They also adapted the flock size to suit the time they can spare on-farm, i.e. taken into account the family or the off-farm activity constraints. So from 1 year to the next one, the flock size could be divided by two or more. The animal performances reached a high level (1.3 lambs per ewe per year) and were relatively homogeneous.

The 'technical ambition hobby strategy'. This strategy aimed at maximising productivity of the flock with a given flock size. The farmers started the farm activity with a technical ambition, long after they had started to work often as salaried workers. They often had inherited the farm from their grand parents and, therefore, were deeply attached to it. Their off-farm activity rhythm, often related to agriculture, allowed them to get quite a lot of free time during the week. Their spouse did not work on the farm; farming was a personal activity. This strategy consisted in limiting the flock size and in implementing a productivitydriven livestock management. Either they were building the flock, but targeted a flock size less than 250 ewes or they did not want to increase their flock size. They managed several periods of mating and lambing; they produced lambs under out-of-season contract, and contributed to quality deliveries. This strategy was adopted by two kinds of farmers: those who had been set up for a while and expected a small income, and others who have just set up and expect neither income nor money loss from farming. Their animal performances reached 1.2 lambs per ewe per year and were relatively homogeneous.

The 'family and simple strategy'. This strategy aimed at combining several incomes to make a living and allowed women to get a social status by being an official farm manager even if they did not make any important decision on the farm alone. All the members of the household contributed to farming and sometimes to several off-farm activities. The strategy consisted in avoiding the tensions due to the combination of off- and on-farm activities. Offfarm activities were often seasonal or only part-time, as craftsman or agricultural or forestry contractors. Often the men who worked as independent did not hesitate to give up an off-farm work-gang if they considered it incompatible with the farm work to be done. The production goals and the farm size were modest. These farmers were not interested in having a very technical approach of sheep farming even if sheep farming was a professional lucrative activity for them. They said that they spent more time on farming but earned less money than with their off-farm activity. They tried to make the livestock management easier by minimising the number of animal batches and the number of interventions on the herd: the rams were with the ewes nearly all the year long, they specialised on selling fattened lambs out of quality supply chain. Some of them minimised the number of times they fed the animals, and the number of types of feeding ration. Animals went away from the farm during summer on a summer mountain pasture, and continuous grazing was implemented on the farm the rest of the year. The performances were medium but very variable (1.1 lambs per ewe per year).

The 'uncertainty strategy'. This strategy aimed at making the dream of farming true whatever the animal production. These farmers encountered many difficulties: they had set up several times, with different animal productions, had gone into economical problems and difficulties to get enough land. They also changed their off-farm activities. Often the flock was being built up. Later on, they hoped to get an income out of farming, and some of them hoped to become full-time farmers. The livestock management observed on the year we made the survey was far from the livestock management they would like to implement. Because of the climatic and sanitary difficulties and because of the lack of time for farming they did not manage to do what they wanted. The data collected in the survey were not precise enough about the numbers of ewes and lambs to assess the animal performances.

\section{Discussion}

We actually observed a diversity of sheep farming management strategies. But the level of farming income expectation and the level of availability for farming did not explain the diversity to the degree expected. Indeed, the strategies were differentiated by two factors made of combinations of variables representing the 'level of motivation of the farmer to get good technical animal performances' and the 'more personal fulfilling $v$. the familial business conception of farming'. The $27 \%$ of the diversity explained by the two factors we extracted from the MFA is rather low. It can be explained by the fact that the diversity had already been reduced by the step of building the synthetic variables. This step had significantly reduced the diversity by gathering elementary data that were consistent together and produced new variables rather independent of each other. In this new system of representation, the set of data was more spherical. Finally, the first two factors provide us only with general trends of differentiation of the strategies, which were empirically validated by the multiplejob holders at meeting of results presentation.

The level of motivation of the farmer to get good technical animal performances explained well the diversity of the strategies

Multiple-job holders constituted a heterogeneous population also from a strictly technical point of view. The analysis of their flock management and productivity confirmed what some social scientists had already mentioned (Buttel and Larson, 1982; Fuller, 1990; Saraceno, 1994): the multiplejob-holding farmers did not constitute a world apart from full-time farmers.

The factor one was mainly determined by the combination of the three variables, 'chronology of the on- and 
off-farm activities' (Chro2 and 3), 'farming dynamics' variables (Dyn1 and 4) and 'lamb-production strategies' (Pro1 and 4) (Table 5). This combination allowed us to precise the opposition already made by social scientists between the multiple-job-holding situations that are imposed and the ones which are chosen (Blanchemanche, 2000). In the former, the flock management did not aim at any production or selling objectives, the flock did what it wanted, whereas in the latter one, the farmers had ambitious production and selling objectives. They looked like the 'aspiring farmers' that Bessant identified (2000). In between there was a range of lamb-production strategies.

The diversity observed among multiple-job holders reminded us of the ranges of the lamb-production strategies (Dedieu et al., 1991; Laignel and Benoit, 2004) and the flock productivity (Dedieu et al., 1997; Laignel and Benoit, 2006) observed among full-time farmers in Massif Central. As shown by Saraceno (1994) in northern Italy, it was noticeable that getting high level of performances is also part of the objectives of some multiple-job-holding farmers. Flock productivity (Table 5) seemed to differ between groups (although the numbers of farms per group did not authorise any statistical assertion and the variability was important): they ranged from 0.9 ('shock absorber strategy') to 1.4 ('high productivity strategy). The different levels of flock productivity were consistent with the sheep-farming management strategy we identified. It was clear that the farmers with the 'high-productivity strategy' or the 'hobby with technical ambition strategy' aimed at getting a high level of performances, at which the other groups did not aim. The variability of the productivity within the strategy types shows that there are performance improvement perspectives respecting the farming-management strategy of the farmers. The range of lamb-production strategies and the flock productivity observed among the multiple-jobholding farmers allow us to hypothesise that they do not contribute in the same way to the deliveries of the agrofood-supply chain in terms of lamb quantity and quality and repartition of the sales in the year. Unlike farmers with the 'shock absorber strategy', farmers with the 'highproductivity strategy' or the 'hobby with technical ambition strategy' met well the requirements of the agro-food-supply chain.

\section{Distinguishing between and analysing objectives of production and objectives of farming income to explain the diversity of the strategies}

Because it is a part of factor 2, the 'more personal fulfilling v. the family business conception of farming' which can be summarised into 'the role of farming in the household', the variable level of farming income expectation contributed to explain the diversity of the strategies. But distinguishing between objectives of farming income and objectives of production, and analysing how they overlap would better explain the diversity of sheep-farming management strategies of multiple-job-holding farmers.
As social scientists had already showed, we observed the range from low to high levels of farming income expectation to meet the family needs. But we also observed two additional modalities which were: 'not expectation at all' (Inc1) and 'expectation of no gain but no loss' (Inc2). Our observations confirmed that multiple-job holding in farming can be more a lifestyle choice than an economic need (Barlett, 1986). Indeed, we encountered situations in which farming was just expected not to cost ('technical ambition hobby strategy'), or even cost money to the household ('shock absorber strategy'). This variable was obtained from what the farmer had declared. It should be confirmed by a detailed microeconomic study. Economic objectives other than getting an income should be considered as capitalising.

Considering the difference in the level of farming income expectation was not enough to explain the diversity of the strategies for two reasons. First, objectives of income (contributor to the factor 2; Table 5) and objectives of production represented by the different lamb-production strategies (contributor to the factor 1, Table 5) were found to be independent. It means that at one level of income expectation, multiple-job-holding farmers had different levels of production objectives linked to different sheepfarming managements (Figure 1). Second, factor 1 and factor 2 explained the same amount of the diversity, 14 and $13 \%$ respectively.

Multiple-job-holding farmers with 'high-productivity strategy' and 'the technical ambition hobby strategy', both, aimed at getting high levels of performances, but the former cared about income, while the latter just expected not to loose money with farming. Both implemented lambproduction strategy Pro4 (meat/pure bred rams, three lambings every 2 years, several quality and out-of-season lambs selling contracts; Table 3), which is the local emblematic sheep-management system, which the producers' groups promote among full-time sheep farmers who aim at the highest productivity and the highest revenue (Benoit et al., 1999).

Multiple-job-holding farmers who had no farming income expectation either expecting no loss of money ('technical ambition hobby strategy') or even accepting loss of money ('shock absorber strategy') covered the whole range of objectives of production from 'no objective' (Pro1; Table 3) to high-level performance (Pro4; Table 3).

It is also noticeable that the level of motivation for animal production performance was independent of the flock size (Table 6): (1) big and smaller flocks were found with the 'high-production strategy' and (2) big and smaller flocks were found with the 'shock absorber strategy'.

\section{A complex relationship between work organisation on farm} and livestock-farming management strategy

One of our initial hypotheses was refuted: diversity of strategies was not well explained by the ways multiple-jobholding farmers organised the work on the farm. Only two 
strategies were specified by a modality of the work organisation strategy variable. In fact, multiple-job-holding farmers rarely adapted only the flock management to the off-farm activity rhythm. Most often they combined adaptations of the off-farm activity rhythm and the labour force available on the farm. Some also accept or even like to work far more than others. Four points can be pointed out to better understand the role of the way to organise the farm work in defining the sheep-farming management strategies of multiple-job holders.

(1) The variable we built to represent combinations of adaptation of the rhythm of the off-farm activities, labour force pattern and flock management used by farmers to cope with the work to be done on the farm contributed to explain the diversity of the strategies, but little. Indeed, we showed that some modalities of the work variable contributed to factors 1 (Wor1, 19.8\%) and 2 (Wor3 and 4, $17.1 \%$ together), some others did not (Wor2 and 5) (Table 5). Only two strategies were specified by a modality of the work variable: 'shock absorber strategy' was specified by the modality 'livestock management mainly adapted to the off-farm activities rhythm on a day-to-day basis' (Wor1), and 'high productivity strategy', by the modality 'adaptation of the labour force on the farm to the farming needs' (Wor3). The other strategies were not specified by a single work variable modality.

(2) A few strategies were based on flock managements types whose justifications were at least partly based on work organisation argumentations. We encountered two types of arguments. One was to implement a lambproduction strategy such as Pro1 or Pro2, in which (Table 3) rams with ewes are produced all year round. Here the idea is to spread lambings and to avoid workload peaks. The other one implements lamb-production strategy such as Pro3, with one limited mating period per ewe per year, forecasted in order that the lambing period and the vacations from the off-farm activities matched.

Moreover, we observed, in some households, parallel evolutions between the availability of the workforce for farming and the size of the flock. Several farmers mentioned the limited-size flock as a condition to be able to implement the Pro4, time-demanding lamb-production strategy. These observations suggest that limiting the flock size could be another way to limit and to cope with the work.

(3) But in most observed cases, farming management and especially the flock management were not always constrained by the non-availability of the farmer due to his off-farm jobs and neither adapted to it. So the view of farming as subordinated to the off-farm rhythm is too much of a caricature.

Multiple-job holder managed to be available for farming, whether they worked off farm as salaried or independent workers. The availability for farming relied on the possibility of extending the labour force and adjusting the off-farm activity rhythm so as to be fully available for farming during some critical periods of the flock management. It was organised either on a day-to-day basis or on a yearly basis. They anticipated a lot the most labour-demanding events of the farming management so that they matched the vacations from the off-farm job. Some salaried farmers also had their off-farm jobs only at night or during the weekends, and were available for farming every day. We observed them especially in the 'technical ambition hobby' strategy and the 'family and simple' strategy, where the farm-income expectations were limited or non-existent. These adaptations of the off-farm activities could be emphasised in our study in which: (1) salaried annual part-time farming cases were dominant, whereas seasonal part-time farming due to tourism was absent, unlike in Madelrieux et al. (2004); (2) sheep farming allows to have successive time periods which differ by the quantity of daily labour required, unlike in dairy farming for example.

(4) We also observed that multiple-job-holding farmers did not always aim at reducing or simplifying farm work even if this work was poorly or less remunerated than their off-farm job and even if their availability for farming was limited. This confirms what Fall and Magnac (2004) had already shown: multiple-job-holding farmers in Europe do not allocate time to the on- and off-farm activities according to a single economic rationality, but also on the basis of personal values (Gasson, 1973; Salmona and De Vries, 1974; Sens and Soriano, 2001).

\section{Conclusion}

We observed a diversity in sheep-farming management strategies of multiple-job holders. The types of flock management and flock productivity we observed proved that multiple-job-holding farmers constitute a heterogeneous population also from the technical point of view, and do not constitute a world apart from the full-time farmers. The level of farming income expectation and the level of availability for farming did not explain well the diversity of strategies. This diversity was better explained by the crossing between the levels of farming income expectation and objectives of production, which were found to be independent of each other. The work organisation on the farm was mainly not fully subordinated to the off-farm activity rhythm. We observed a diversity of ways to combine the time flexibility of the off-farm activities, the labour force available on the farm and the flock management to carry out the work to be done on the farm. How the multiple-jobholding farmers faced the work to be done on the farm explained little the diversity of the strategies.

Looking more closely at the range of the flock management and farming dynamics of multiple-job holder would be useful to thouroughlly investigate statements such as 'the farming systems of multiple-job holders contribute to the sustainable development of rural area and are noticeable for their capacity of adaptation'. Indeed, this study already showed that according to the diversity of the household work pattern and farming dynamics, lamb-production strategy and flock productivities, we can hypothesise that 
multiple-job-holding sheep farmers do not contribute the same way to the production of quality lambs, agro-foodsupply chain and rural land maintenance, neither have they the same adaptation capacity.

The study of the livestock-farming systems of multiplejob-holding farmers showed the necessity of considering: (1) objectives other than income objectives, and to grade the objectives to make a good analysis of the livestockfarming systems; (2) the household level to catch these objectives and their evolution to study livestock-farming systems like full-time system or multiple-job-holder system. Livestock-farming systems of multiple-job holders appear now to us similar to livestock-farming systems of full-time farmers but we have to emphasise the weight of the noneconomic motivations in the way the livestock-farming systems are managed. The independence between objectives of production and of income, the fact that multiple-job holders managed the farms to be as much available as possible on the farm whatever their farming income expectation are, the fact that they did not always intend to reduce the work to be done on the farm or even implemented time-demanding practices, make us think that there are non economic benefits of farming in multiple-job holding which interfere strongly with the way livestock farming is managed. In order to understand how multiplejob-holding farmers manage their livestock, we need to identify all the benefits expected from farming and their hierarchy, and further we have to know how these expected benefits are translated into objectives of productions and objectives of management.

\section{Acknowledgements}

The authors wish to thank $\mathrm{Dr}$ Sylvie Cournut (ENITAC, FRANCE) for help with statistical analyses, and Dr MarieClaude Roland (INRA, FRANCE) for helpful comments.

\section{References}

Barlett PF 1986. Part-time farming: saving the farm or saving the lifestyle? Rural Sociology 51, 289-313.

Benoit M, Laignel G and Liénard G 1999. Facteurs techniques, cohérence de fonctionnement et rentabilité en élevage ovin allaitant. Exemples du Massif Central Nord et du Montmorillonnais. Rencontres autour des Recherches sur les Ruminants 6, 19-22.

Bertin J 1977. La graphique et le traitement graphique de l'information. Flammarion, Paris.

Bessant KC 2000. Part-time farming situations among Manitoba farm operators: a typological approach. Canadian Journal of Agricultural Economics 48, 259-277.

Blanchemanche S 2000. La combinaison d'activités professionnelles des ménages agricoles. L'exemple du département de I'Isère. Thèse de sociologie Université de Paris $X$.

Blanchemanche S 2002. Interpréter la combinaison d'activités des ménages agricoles - stratégies sociales et organisation du travail. INRA Fasade 13, 1-4. Buttel FH and Larson Jr. OW 1982. Political implications of multiple jobholding in the US agriculture: an exploratory analysis. Rural Sociology 47, 272-294.

Card SK, MacKinlay J and Schneiderman B 1999. Readings in information vizualisation: using vision to think. Morgan Kaufman, San Francisco, CA, USA.
Dedieu B and Servière G 2001. Organisation du travail et fonctionnement des systèmes d'élevage. Rencontres autour des Recherches sur les Ruminants 8 , 245-250.

Dedieu B, Jestin C and Servière G 1991. Exploitations associant vaches laitières et brebis viandes en Margeride: importance respective des deux troupeaux et fonctionnement des systèmes. Fourrages 125, 117-128.

Dedieu B, Chabosseau JM, Benoit M and Laignel G 1997. L'élevage ovin extensif du Montmorillonais entre recherche d'autonomie, exigences des filières et simplicité de conduite. INRA Productions Animales 10, 207-218.

Fall $M$ and Magnac T 2004. How valuable is on-farm work to farmers? American Journal of Agricultural Economics 86, 267-281.

Fiorelli C and Dedieu B 2004. Les transformations des systèmes de production vont-elles dans le sens de la multifonctionnalité de l'élevage? Implications pour les recherches sur les systèmes d'élevage. Proceedings of the Société Française d'Economie Rurale (SFER) Conference: «Les systèmes de production agricole: performances, évolutions, perspectives», 18-19 November 2004 Lilles, France. Retrieved June 12, 2007 from http://www.sfer.asso.fr/index.php? passe $=$ yes\&action_menu $=$ open\&id_menu $=4 \&$ sid $=1 \&$ section $=325 \&$ id_col $=71$.

Fiorelli C, Pailleux J-Y and Dedieu B 2005. Les éleveurs d'herbivores en 2000: un ménage sur cinq est pluriactif. Agreste Auvergne 64, 1-4.

Fuguitt GV 1961. A typology of the part-time farmer. Rural Sociology 26, 39-48.

Fuller AM 1990. From part-time farming to pluriactivity: a decade of change in rural Europe. Journal of Rural Studies 6, 361-373.

Fuller AM 1991. Multiple job-holding among farm families in Canada. In Multiple job-holding among farm families (ed. MC Hallberg, JL Findeis and DA Lass), pp. 31-44. lowa State University Press, Ames, IA, USA.

Gasson R 1973. Goals and values of farmers. Journal of Agricultural Economics 24, 521-537.

Gibon A, Rubino R, Sibbald AR, Sorensen JT, Flamant JC, Lhoste P and Revilla R 1996. A review of current approaches to livestock farming systems in Europe: towards a common understanding. EAAP publication 79, 7-19.

Girard N and Hubert B 1999. Modelling expert knowledge with knowledgebased systems to design decision aids: the example of a knowledge-based model on grazing management. Agricultural systems 59, 123-144.

Girard N, Bellon S, Hubert B, Lardon S, Moulin CH and Osty PL 2001. Categorising combinations of farmers' land use practices: an approach based on examples of sheep farms in the south of France. Agronomie 21, 435-459.

Hubert B, Girard N, Lasseur J and Bellon S 1993. Les sytèmes d'élevage ovin préalpins: derrière les pratiques, des conceptions modélisables. Etudes et Recherches sur les Systèmes Agraires et le Développement 27, 351-387.

Laignel G and Benoit M 2004. Production de viande ovine en agriculture biologique comparée à l'élevage conventionnel: résultats technico-économiques d'exploitations de plaine et de montagne du nord du Massif Central. INRA Productions Animales 17, 133-143.

Laignel $G$ and Benoit M 2006. Viande ovine bio, Production économiquement rentable sous conditions: technicité, économie de charges, aides.... Alternative Agriculture 75, 4-7.

Madelrieux S, Dedieu B and Dobremez L 2004. How to model work organisation in livestock farms implementing a combination of economic activities? (pre) Proceedings of the Sixth European IFSA Symposium: 'European Farming and Society in Search of a New Contract - Learning to Manage Change', 3-8 April 2004, Vila Real, Portugal, pp. 269-282.

Salmona M and De Vries H 1974. Pour une psychologie du travail agricole, résultats d'une étude psychologique de l'éleveur ovin. Applications pédagogiques. Economie Rurale 101, 43-50.

Saraceno E 1994. The modern function of small farm systems: an Italian experience. Sociologia Ruralis 34, 308-328.

Sens S and Soriano V 2001. Parlez-moi d'élevage. Analyse de représentations d'éleveurs. Educagri Edition, Dijon, France.

Veysset P, Bebin D and Lherm M 2005. Adaptation to agenda 2000 (CAP reform) and optimisation of the farming system of French suckler cattle farms in the Charolais area: a model-based study. Agricultural Systems 83, 179-202. 